\title{
TRUMP AND THE FOREIGN POLICY CRISIS IN THE UNITED STATES
}

\author{
Tariq Aziz \\ M.Phil Scholar \\ Hazara University \\ Mansehra, Pakistan \\ tariqazizdurani@gmail.com \\ Fahad Muhammad \\ M.Phil Scholar \\ Hazara University \\ Mansehra, Pakistan \\ fahadkhattak8@gmail.com \\ Waheed Shah \\ M.Phil Scholar \\ Hazara University \\ Mansehra, Pakistan \\ waheedhu16@gmail.com
}

\begin{abstract}
Under Donald Trump's administration, American foreign policy's controversial and anti-traditional path has already disrupted decades of U.S strategy, conveying an extreme response from both allies and enemies. This steady decline not only confuses the close allies of the USA in Europe and Asia but also brings new insight to the growing and revival powers that the age of historic global dominance in the United States is over. The decline in US superpower status was, however, accidentally not due to "national below-reach," but through a gradual loss of power and authority including the sacrifice of power. Under Trump's administration, U.S. foreign policy is shifting the U.S. relationship with former friends and harming their potential to achieve the expected results.
\end{abstract}

KEYWORDS: US Foreign Policy, Russia, China, Iran, Donald Trump, North Korea

\section{INTRODUCTION}




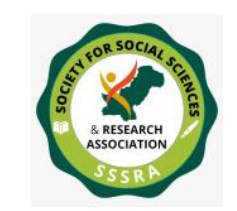

Pak. Journal of Int'L Affairs, Vol 4, Issue 3 (2021)

Trump and The Foreign Policy Crisis ...

President Trump's two years in office have already shattered decades of US diplomacy. Both Trump's supporters and detractors have reacted strongly to his presidency. The President's erratic statements and constant tweets have had a significant impact on the United States' relationship with both allies and adversaries. Critics claim that President Trump has broken with international norms by setting out the United States' global strategy and then starting to dismantle it piecemeal. According to them, President Trump is systematically dismantling the post-war liberal world order one step at a time. United States President Barack Obama, 2017 It's hard to predict where his administration will go or how much harm he will inflict on our nation because he is "so uncertain, so careless, so immature, so full of blind self-consciousness," according to a Los Angeles Times editorial. Not only have disgraceful "policy choices" undermined the democratic standing of this state around the world, but they have also put the world at risk because of climate change (Our Dishonest President, 2017) So those opposed to the new president's "dangerous and selfish policies should make their voices heard," according to the author.

The sentiments expressed by both domestic and international media outlets were similar. When it comes to delicate global issues, President Trump's "crudely threatening, aggressive and know-nothing approach to delicate global issues encircled the world from Moscow and the Middle East to Beijing, sinking adversaries and allies into a dark spiral of growing strategic instability," the Observer wrote in its review of Trump's first 100 days in office. In 2017, the Observer examined Donald Trump's foreign policy. His foreign policy has been a failure and a mess in the past, as evidenced here. They argue that these accusations are unjustified and Trump's policies are just as typical as those of previous administrations. In contrast to his tweets and speeches, he is viewed as more traditional in his actions. However, the "America First" agenda is seen by these critics as an attempt to bolster the United States' global leadership position, rather than an act of isolationism. Trump's foreign policy direction was examined in a paper by Benkowski and Potter (Benkowski and Potter, 2017) in the following year.

\section{THE IDEOLOGY OF TRUMP}

The idea that Trump has squandered decades of America's military, economic, and technological superiority is false. There have also been negative and long-term developments during Obama's presidency that have weakened US global leadership. Evidence of a weakening grip on the global economy; (Plecher 2019) the failure of its vast military superiority to achieve planned policy objectives, particularly in the active Middle East theatres; (Brand and Edelman, 2017) the rapid decline of its technical primacy; and the emergence of rival competition with highly autonomous and assertive 


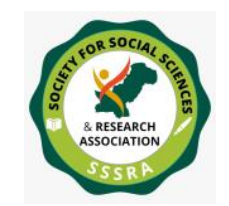

Pak. Journal of Int'L Affairs, Vol 4, Issue 3 (2021)

Trump and The Foreign Policy Crisis ...

foreign-policy behaviours in Latin America and Europe. Because of weakened and growing global forces, it is impossible to deny that America's ability to achieve desirable foreign outcomes has already been limited. According to the examples provided in the report, the phenomenon was evident in the increasingly sectoral approach of former friends and allies. In the new international order, problem-by-problem partnership and anti-cooperation appear to be the norm rather than traditional partnerships.

When their concerns diverge significantly from those of the United States, the partners adopt a strategy that is clearly at odds. When their interests overlap, they work together. A changing global climate necessitates that the United States maintain its ability to govern the world by promoting liberal global order and its human rights conventions. Friends and allies are less trusting of each other as a result of Trump's policies. Even the most important foreign allies are adjusting their ties to the United States in light of the shifting international environment. By placing a high priority on economic nationalism and national security, the United States has been transformed into "USA Alone." From a Long's (2018) perspective: Recent studies of US foreign policy show that the United States is on a path that will eventually put its global leadership at risk.

\section{PERPLEXED ALLIES}

On a wide range of mutual and global issues, the United States has been unable to recognise the sensitivities of its European allies during Trump's presidency. It was already frustrating to see the "Pivot to Asia" and Obama's "weak" response to Russia's invasion of Syria, as well as his conflicted response to the Ukraine crisis, as evidence that European allies live in a different era. A high level of scepticism about Trump's presidency existed in 2021 (Ali et al. ), as evidenced by his relationship with the United Kingdom, America's most significant European ally. Donald Trump used a Twitter spat between London Mayor Sadiq Khan and Prime Minister Theresa May following a terrorist attack in June 2017 to enrage people across British politics. State visit trappings and an audience with the queen were quietly discarded as a result. In the Washington Post, Anne Apple Baum wrote: "The reaction from Trump's trip to the UK will be remembered for years to come." Applebaum (2018, as cited in this article) (Applebaum) By calling it a "trip from hell" by the Guardian editorial board, they said Trump's United States can no longer be considered a reliable partner for the countries of Europe that support liberal democratic values. There has never been anything like it in Europe or the United Kingdom." Since Trump's remarks on Brexit and migration in the UK, protests have been taking place across the continent. For this reason, the United Kingdom may now choose to distance itself from Trump following his recent tumultuous trip to Europe. Khan and his associates (2020) 


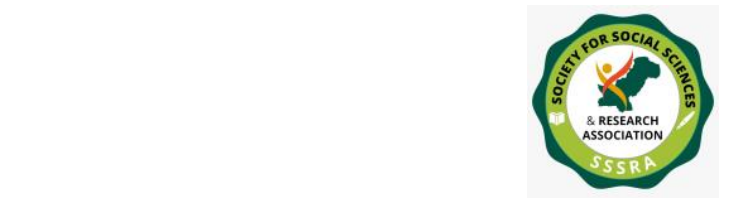

Pak. Journal of Int'L Affairs, Vol 4, Issue 3 (2021)

Trump and The Foreign Policy Crisis ...

Aren't we past the point of realising that the United Kingdom is just another American ally, not a special one? According to the Brexit vote, many people questioned the UK's concern for "close connection" with the United States.

The year 2018 (Dejevsky, 2018) Since Trump's declaration that Jerusalem is Israel's capital, longtime friends have been placed on opposing sides, resulting in tensions between the two countries. Opponents of the decision by UN Secretary General Ban Kimoon to recognise Jerusalem as the capital of Israel have been strong (AOL, 2017).

Xenia Wickett says that President Trump's temperament isn't the only factor at play. As a result of Trump's election, the regional interests and focus of the trends and immigration trends she mentions are expected to change. Another way of saying it: Given that "the Trump years may be significantly different from anything that has passed previously," institutions and agreements like NATO, IAEA, and the Nuclear NonProliferation Treaty are cited in the report as a secondary cause for the decline in intercontinental relations. "As their significance diminishes, transatlantic coordination tools are deteriorating."

The relationship between the United States and France has grown in importance because France is the only EU country with a permanent seat on the UN Security Council. This is because of the current political climate in the Atlantic Alliance and the Brexit vote. Even though the Iraq conflict was still unclear in 2003, the link had already been established. Although the removal of Syrian forces from Lebanon in 2005 seemed to heal the rift, disagreements over Iran's nuclear programme and NATO involvement in Libya remained. President Emmanuel Macron's effort to revive the European project as a means of reinvigorating France's position as a world power is a response to Trump's presidency, which has left a void that must be filled. Since the 1930s, France has learned the hard way that it can no longer rely on its transatlantic ally (Nougayrede, "Isolationism and Foreign Policy"). This shows that European priorities are becoming increasingly distinct from those of the United States. According to Macron, "the current unpredictable nature of US foreign policy is calling into question some of our benchmarks, while a broad room has been held open to the politics of force and fact accomplished in Europe, the Middle East, and also Assia," he said in March 2017. As long as we want to see peace and stability replaced by violence and chaos, we must put ourselves in harm's way and meet the people with whom we intend to work. To N. Nougayrede, this is the case. There is a consensus among French leaders that reviving the European Revival will require reintroducing the Franco-German engine. This has been boosted by Trump's disdain for NATO and the EU. It is not clear whether Trump's claim that he proposed that France withdraw from the EU in June 2018 in exchange for a better bilateral agreement with 


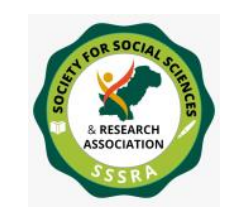

Pak. Journal of Int'L Affairs, Vol 4, Issue 3 (2021)

Trump and The Foreign Policy Crisis ...

America was confirmed or denied by the White House or Elysee Palace. In Al Jail, 2018), "America needs to hold the ground as long as Trump remains in office," they say when it comes to Europe's "strategic void." In the year 2017 (Nougayrede) More than any other European country, Germany's anti-Trump sentiment runs deep. Trump criticises China's large trade surpluses and free use of US security guarantees in both of these ways.

According to Angella Merkel, Germany's reliance on the United Kingdom and U.S. is "somewhat over." She urged the rest of the European Union to take "their fate into their own hands."

"Theil, 2017:" Because of its reliance on the US-led liberal order, which is based on universal values and standards and open markets, the German problem is that it relies too heavily on that order. Regardless of how complicated and uncertain it may appear, Germany has no choice but to engage in negotiations with Trump.

Self-awareness and self-organization have risen as Europe's attitude toward the United States has changed over time. In 2018, (Lyuken 2018) Germany has shown that it is ready to meet Trump's demand that it invest 2 percent of GDP by 2024, up from the previous 1.2 percentage points, in Europe's defence plans, which are receiving renewed attention. European allies and Germany have found themselves with no choice but to improve trade ties with other allies, such as Japan and Canada, because of Trump's lack of interest in signing the Transatlantic Trade and Investment Partnership (TTIP).

Germany's foreign minister Sigmar Gabriell's criticism of the Berlin Foreign Policy Forum indicates that the partners are eroding. Rather than follow the shadow cast by the NATO alliance, Germany should follow Trump's lead, he said. "Germany can no longer only respond to US policies, but it must establish its place in the international arena," he said. There will never be a return to pre-Trump relations with the United States. Cornor (2017, p. "Cornor, 2017" (Cornor), In response to Trump's decision to ratify the Iran nuclear agreement, Gabriel said, "It was important for Europe to stay together on this issue." "Cornor" (2017-02-07) People had very different views about North Korea.

With Trump, his allies aren't just in the European Union. Allies such as Japan, Australia and Canada have their own issues with the Trump administration. " There have been 17 missile launches in the region by North Korea, an ICBM test on July 4, 2017, and ongoing construction of Chinese islands in the South China Sea that Japan is concerned about. It is a serious threat to the United States' ability to maintain its own security if North Korea develops an intercontinental ballistic missile (ICBM). Japanese 


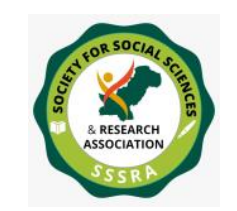

Pak. Journal of Int'L Affairs, Vol 4, Issue 3 (2021)

Trump and The Foreign Policy Crisis ...

taxpayers paid for Trump's financial crimes and trade deficits as well as the costs of maintaining US military presence in Japan before and during the election. When it came to Japan, Trump's combination of economic and security issues was viewed as especially concerning.

Japan has received continued US support on the Diaoyu/Senkaku Islands issue after Washington declared Article 5 of the US-Japanese Security Treaty to apply. In addition to increasing defence spending and appeasing Trump, it was also able to keep Trump at bay by referring to US troops' care and feeding as a "price sharing model." Withdrawal from the Trans-Pacific Partnership (TTP) agreement by Trump has made the financial side more challenging. A revised agreement that excludes the United States is still an option for Japan and 11 other countries. According to Hokotani (2017: 24), To date, it is unclear whether Trump's own recently proposed Indo-Pacific policy and economic infrastructure plan, which he wants to implement with Japan and Australia, will be implemented or if it will match China's financial power.

Staying too loyal to Trump turned out to be a liability, not an asset, during the divorce process. To Japan and other allies, US withdrawal from global institutions and rising tensions on the Korean Peninsula prompted them to worry. Even more complicated, however, are the competing or cooperating with China's Belt and Road Initiative and the uncertainty of U.S.-China relations (BRI). A major blow to US financial dominance in Asia has come from Trump, and Japan is reconsidering its opposition to Chinese initiatives like the Belt and Road Initiative and the Asian Infrastructure Investment Bank that it had previously backed (AIIB). Assia and the rest of the world's Japanese policy does not mean that Japan is shifting its attention from the United States to China.

Throughout the twentieth and twenty-first centuries, Australia has fought alongside the United States in every major conflict. US-Australian Refugees Transfer Agreement was blasted by President Trump in his first meeting with Malcolm Turnbull and he later threatened to "review the stupid deal" via tweet. In 2017 (The Fullilove) With little doubt at this point, this administration would pose significant challenges to Australian objectives and foreign policy, which could even lead to a breakaway from the United States.

Australians are being pushed to reassess their reliance on America when the United States pulls out of the TPP and the Paris Climate Agreement. Scepticism about China's shift to Beijing is growing because of the country's uncertain domestic future and erratic foreign policy. The debate in the state has become polarised, with a heavy 


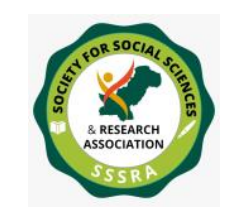

Pak. Journal of Int'L Affairs, Vol 4, Issue 3 (2021)

Trump and The Foreign Policy Crisis ...

emphasis on either pro-China or pro-US positions. It remains to be seen if Trump's "pivot" or "rebalance" replacement plan can be considered a viable alternative as of 2017 (Fullilove, 2017). There is a way (Pompeo, 2018) Canberra's strategic move, which involves "greater cooperation with like-minded regional powers," is a "significant buffer against the twin dangers of an aggressive China and an indolent United States."

Canadian officials are particularly concerned about Donald Trump's disorganised leadership style and personal fragility in light of his declaration that decades of international alliances and agreements are ineffective. Because of his anti-internationalist and vindictive attitude, he contributed to the chaos that erupted. "Kay, 2017," he says. Canada's Foreign Minister Chrystia Freeland responded to Trump's criticism of NATO members for an unequal share by saying, "The reality that our friends and allies have started to doubt the very meaning of their mantle of world leadership places the need to build our own simple and independent path in a sharper focus."

Because of threats made by President Trump to begin negotiating the North American Free Trade Agreement (NAFTA), relations between America and Canada broke down. There were threats to nearly 2.5 million jobs and 75 percent of Canada export sales. By filing a complaint with the World Trade Organization against Washington's non-dumping and anti-subsidy duties, Ottawa launched an all-out trade war with the United States (WTO). Trump administration's new USMCA, which merges NAFTA with Trump administration, was also criticised in the United States as "more TPP (in the new trade deal) than not" and "a fresh package (TPP) and a new line," even in the United States. When it comes to 2018 (Collins, 2018) Trump's administration has caused friction with allies and friends on every front, from defence to economy to foreign policy, and has urged them to follow the sectoral strategy.

In close allies like India and Saudi Arabia, this distributional strategy is evident. Despite the threat of U.S. sanctions, India has agreed to buy a Russian missile defence system for $\$ 5$ billion. Saudi Arabia has threatened to retaliate against the "warnings" of US sanctions on Jamal Khashoggi, a Washington Post journalist and a popular Saudi Arabian critic who was kidnapped. As a result of Trump's antipathy to international institutions, his zero-sum strategy to delicate global issues, his oblivion of making allies and friends, and his centrality to the world order, the United States paid more than any other country for his presidency. As stated by Perper (2018), "The former leader of the liberal order in the world, which has renounced its leadership role, has encouraged China and Russia to pursue their own agendas without much opposition. 


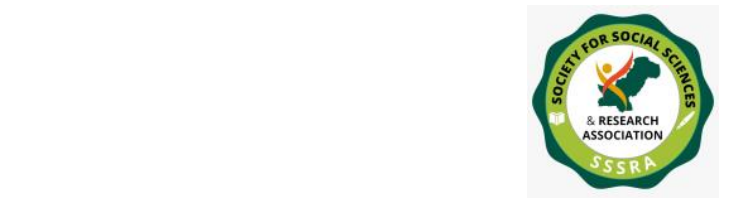

Pak. Journal of Int'L Affairs, Vol 4, Issue 3 (2021)

Trump and The Foreign Policy Crisis ...

\section{THE GREAT POWER COMPETITION REAPPEARS}

\section{a) China: A Power in Rising}

Trump's administration has been confusing and ambiguous to the public for nearly a year now about how and what kind of ties it plans to build with China. It's been decades since the two countries have had an exchange of cooperation and protection policies. As of December 18, 2017, China was listed as a "strategic rival" in the National Security Strategy (NSS, 2017), which aims to avoid direct conflict and embrace healthy competition. China "tries to expel the United States in the Indo-Pacific region" using "oppressive world order dreams" and "financial exploitation," according to the report.

In his speech at the 19th National Congress of the Communist Party of China, he said that China was expected to take centre stage on the international stage and encourage China as an alternative model of development, which made the United States doubtful about its discourse of "peaceful rise" and added anxiety to its rise as a world superpower (CPC). China's economic growth and integration into the post-war international order have "always been assumed" to lead to a more liberal China, according to the National Security Agency (NSS). Expanding Chinese power at the expense of other countries' freedoms exceeded our expectations." Angrily, Beijing responded (NSS, 2017). By labelling China a global threat, Trump is promoting a "Cold War mentality" and "great power competition," China's leadership claims.

Predicted a more aggressive relationship with China under Trump's National Security and National Defense Strategies than under previous administrations (NDS). Threatening its neighbours with a combination of "revisionist force" and "predatory economics" while militarising parts of the South China Sea "are just two of the terms used in the National Security Strategy to describe China (NSS). As stated in the statement, the United States wants to gain "Indo-Pacific regional and removal to gain international preeminence soon" in the near future. To put it another way, the U.S. has introduced a zero-sum game into its relations with China. Some of China's long-term threats are shared by U.S. allies, who are alarmed by this hostile attitude. Allies of the United States are reluctant to accept the proposed US policy against China because it comes from the government itself, which has "revised" the international system in large part.

US concerns about trade and monetary policy and Trump's admiration for Trump are all reflected in Trump's instability in China-US relations, which openly questioned the logic of the US pledge to the "one China" strategy. When it comes to North Korea and other international issues, the risk of a downward spiral will not go away. 


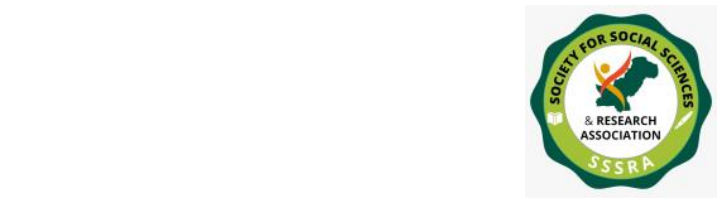

\section{b) Russia: A revisionist Power}

Trump's ties to Russia are also a hot-button topic in the political arena. Cooperation with Russia on counterterrorism and nuclear nonproliferation is widely accepted, but the United States should not overlook differences and ignorance of Russian involvement in Syria and Ukraine. However, any policy based on Trump's refusal to answer questions about Russia's interference in last year's election has been slammed by the American public because of this, even though analysts agree that Russia must play an important role in any conflict involving Syria, Ukraine, Iran and North Korea. There is no doubt that Mark Simaakovsky's assertion that "the President is not at the wheel of USRussian ties" will be difficult to disprove, in the words of Huggins (in 2017)

NSS has exacerbated the recent animosity between the two countries following Trump's public statements to maintain strong relations with Vladimir Putin's Russia. While Russia is attempting to "transform the global order in its favour," according to the 2017 NSS, it also wants to "form a world that is compatible with its authoritarian system," according to the new NDS. Policy and strategy in the United States appear to be at odds with Trump's stated goal of strengthening ties with Russia, which includes a new Magnitsky Act and sanctions on Russian citizens." 2017 (McLaughin and Tamkin, 2017) Trump's hopes for a "upheaval" have thus far failed to materialise like Obama's "change."" Having a great relationship with Russia is still just a dream.

This will give Russia and China the perfect opportunity to re-start the whole thing because of Trump's erratic policy decisions and harsh rhetoric. In spite of international sanctions, China's \$11 billion investment in Russia has been described as a partnership with the US and as a permanent counterweight to US hegemony, while the rest of the world awaits Trump's government for a response. The United States' hegemony is certainly weakened as a result of this cooperation on a wide range of global issues, including North Korea, Iran, and Syria.

China and Russia will be freed from America's declared policy of perceived conflict, according to Australian Foreign Minister Jullie Bishop. According to her, the beginning of this period has already been heralded. "In our worldview, Russia and China hold different positions. According to our assessment, neither Russia nor China pose a military threat to Australia." by means of Gill (Gill, 2018). She has spoken on behalf of a wide range of people over the course of her life. China is ready to seize the opportunity presented by Trump's erratic and contradictory foreign policy toward both allies and foes. 


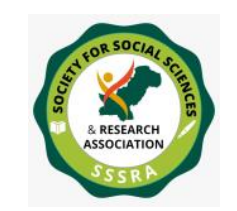

Pak. Journal of Int'L Affairs, Vol 4, Issue 3 (2021)

Trump and The Foreign Policy Crisis ...

\section{c) NORTH KOREA: TRUMP'S OWN MADE VEXING CRISIS}

The standoff between Washington and Pyongyang at the end of August 2017 was the most telling of Trump's presidency and his inability to deal with a global crisis of foreign policy. According to an ex-NSC spokesperson, the crisis was "completely manufactured crises magnified by a response from an American president desperate to show bravado and bluster." The Cost (Price, 2017), The United States believes that North Korea has successfully miniaturised its nuclear weapons, according to the Washington Post on August 8, 2017." "(Warrick, 2017) " "Fire and fury like the world has never seen," according to Trump's unplanned "There is no way to end the standoff between North Korean Supreme Leader Kim Jong-Il and Kim Jong-Un.

Trump's carefree use of the English language sparked the fear of a nuclear exchange. As a result of its resemblance and severity, Robbert Littwak noted that "the Cuban missile crisis [is] in slower motion." As of 2017, "Snager Fill-up process among his closest allies ensued, and the crisis began to subside once Trump had removed himself from the picture. As predicted. Countless people agree that this is the case (Price, 2017) "The US has no desire in regime change or rapid reunification of Korea," a statement backed up by the then-White House advisor, Steve Banon, was made clear when Steve Banon publicly slammed North Korea's army in 2007.

Today, the world is used to Trump's willingness to use "a heavy-wire negotiation strategy aimed at solving one of the most unsolvable standoffs in the world" as his diplomatic approach, thanks to his unconventional diplomatic strategy and his declaration of patience. After Trump and Kim met in Singapore on June 12, 2018, the world's scepticism was not unfounded, according to (Baker 2018) Baker. Without any agreement on anything other than a vague four-point statement and Trump's insistence that "full disarmament" be achieved; Trump's meeting ended in failure (White House, 2018) Experts are in a state of awe. Despite Trump's refusal to set deadlines for disarmament at a leader-level meeting, there has been no improvement in the threat from the Korean issue. (Khan et al., 2021)

\section{d) IRAN: A SHOCKING MISSTEP}

North Korea is the only other nation to appear on a regular basis in the NSS. As a result, all governments in this region are under orders to destabilise their countries and undermine the United States and its allies. Terrorism and ballistic missile production have been linked to Iran's ability to restart nuclear weapons research. No one doubted that Donald Trump's campaign for president would renegotiate the Obama-sponsored Iranian 


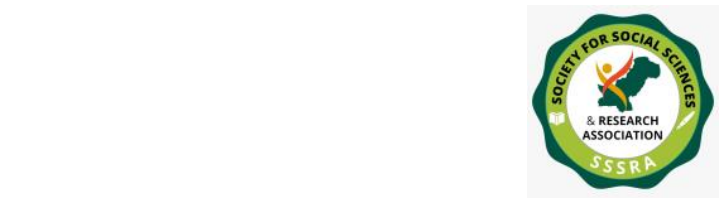

Pak. Journal of Int'L Affairs, Vol 4, Issue 3 (2021)

Trump and The Foreign Policy Crisis ...

nuke agreement. President Trump's announcement that he was pulling out of the nuclear agreement, which brought back memories of the hostage crisis in 1979-80, finally came in October of 2017.

This could be seen as a risky move because of the complicated history between the United States and Iran, which makes it nearly impossible for Trump to reach a similar agreement with Tehran, much less one as large as the Joint Comprehensive Plan of Action (JCPOA). In Malcolylm Byrne's words: "Trump's squawking may satisfy his supporters, but it has also unintentionally poisoned the environment for any potential negotiations." While he may view it through a "domestic-political" prism, the European allies of the United States will oppose it. I'll say it this way: As well as raising suspicions, the message sparked a confrontational debate between the government's hardliners and its allies. There will be ramifications for US-allied relations if Washington pulls out of the nuclear agreement. The United Kingdom, France, and Germany have all expressed serious reservations about this controversial move. If these countries are able to withstand the direct heat of the new US restrictions on European companies' trade in Iran, the question remains open. Despite Trump's latest offer of an immediate meeting with the leaders of Iran, Tehran appears ready to play a long game with Trump.

\section{CONCLUSION}

New Gallop data shows that US governance approval has fallen to a "historic low" in 65 states, putting the country even lower than China in the global rankings. "America First" rhetoric, Trump's disregard for international cooperation and economic nationalism, the loss of Western allies' unity in the face of China and Russia's growing threats, and Trump's abrogation of dominance in multilateral agreements such as the TPP and Paris Climate Agreement all contributed to the rise of the world's unrivalled superpower."

There is still a long way to go before Trump's "USA First" strategy can be judged a success or failure, according to the Gallop report. As a result, it is clear that most of the US's partnerships and relationships could be in jeopardy if the world's opinion of the United States changes. As far as long-term threats go, President Xi's "Chinese Dream" isn't one of them. Rather, the US has been on a path for several years that has exposed this rising and expanding power structure. "Unspeakable brutality" and "national underreach" were not to blame for the decline of world leadership, but rather, it was a voluntary loss of authority and responsibility. On the one hand, Richard argues that this abrogation should not be confused with interventionism, but it has unquestionably been reflected in the US that is "no longer taking the lead" in sustaining partnerships, or in constructing regional and global structures that set the rules for foreign relations. For the 
first time in its history, it is abandoning its role as a central figure in establishing international law and treaties.

There are obvious long-term consequences to Trump's approach. For example, by Trump's age - if this pattern continues in his years - the United States will no longer be the country that keeps friends allied and dissuades their adversaries, and whose diplomatic position gives the United States an unchallenged world leadership role. There are no hard numbers yet, but Trump's age will likely be seen as the beginning of the end of decades of accepted American world leadership. 


\section{REFERENCES}

Ali, S., Khan, M. F., \& Aftab, N. (2021). China Pakistan Economic Corridor and Regional Integration A Liberal Approach. Pakistan Journal of International Affairs, 4(2).

Applebaum, A. (2018, July 15). The Backlash from Trump's Britain's Visit will be Felt for Years to Come. Washington Post.

Baker, P., \& Hun, C. (2017). Trump Threatens 'Fire and Fury' Against North Korea if It Endangers U.S. The New York Times. Retrieved from ttps://www.nytimes.com/2017/08/08/world/asia/north-korea-un-sanctionsnuclear-missile-united-nations.html

Baker, P., \& Hun, C. S. (2018, March 19). Trump's Abrupt 'Yes' to North Korea: The 45 Minutes That Could Alter History. New York Times.

Batchelor, T. (2018, January 16). The US and Europe are Drifting Apart and not Just because of Trump, Finds Chatham House Study. Independent.

Benkowski, J and Potter, A, B (November 1, 2017), The Center Cannot Hold: Continuity and Change in Donald Trump's Foreign Policy, War on the Rocks

Bennetts, M. (2018, October 4). The US Threatens India with Sanctions over \$5bn Deal to Buy Russian Missile Defense System. Times.

Brands, H., \& Edelman, E. (2016). The crisis of American Military primacy and the search for strategic solvency. Parameters, 46(4), 27.

Brown, K. (2014). In many ways, the «China dream» is not different from the American one. The Guardian.

Byrne, M. (2017, October 17). The Trump Administration's Tragic Misstep on Iran. New York Times.

China hits back at America's 'cold war mentality'. (2018, July 20). Retrieved from https://www.scmp.com/news/china/diplomacy-defence/article/2124914/chinahits-back-trumps-selfish-isolation-after-us 


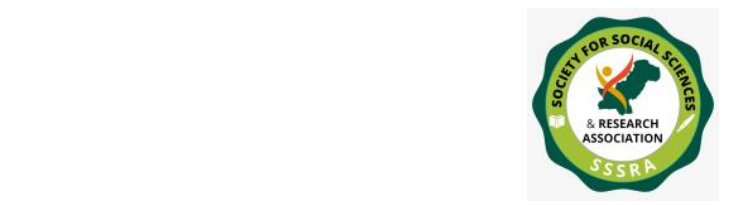

Collins, M. (2018, October 3). New Trade Deal with Canada, Mexico Borrows Heavily from Pact that Trump Abandoned. USA Today.

Connor, T. O. (2017, December 5). The US will 'Never be the same' after Trump, Germany says. Newsweek.

Dejevsky, M. (2018, November 30). The UK's Obsession with the 'Special Relationship', not Donald Trump, is Theresa May’s Real Problem. Independent.

Fullilove, M. (2017). Down and out down under Australia's Uneasy American Alliance. Foreign Affairs, 96, 28.

Gill, B. (2018). US allies aren't buying its new strategies to confront China.

Haass, R. (2017). America and the great abdication. The Atlantic, 28.

Herman, S. (2018, July 13). Trump Denies Troubled Ties with Britain after Bashing PM in Interview. VOA News.

Hikotani, T. (2017). Trump's Gift to Japan: Time for Tokyo to Invest in the Liberal Order. Foreign Affair. 96, 21.

Huggins, T. (2017, December 29). Despite Trump's Hopes and Critics' Fears, US-Russia Relations remain Sour. CNBC.

Jalil, J. (2018, June 29). Donald Trump Suggested to Emmanuel Macron that 'France should Leave EU. Telegraph.

Julian, B. (2018). World's confidence in US leadership under Trump at a new low, poll finds. The Guardian.

Kay, J. (2017). Trudeau's Trump Bump: How a Smaller America Gives Canada Room to Grow. Foreign Affairs. 96, 35.

Khan, M. F., Ali, S., \& Aftab, N. (2020). The Institutional Development of SCO \& Geopolitics of Central Asia. International Journal of Social Science Archives.

Khan, M. F., Ali, S., \& Khan, H. U. (2021). Ethnic Conflict and the Political Instability in Afghanistan. Pakistan Journal of International Affairs, 4(2). 


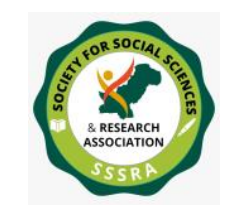

Trump and The Foreign Policy Crisis ...

Long, H. (2018, January 24). America First is not America Alone: Trump Aims to Reset Global Opinion about him in Davos. Washington Post.

Luyken, J. (2018, January 11). German-US Relations after a Year of Trump: What has changed? Local De.

McLaughin, J., \& Tamkin, E. (2017). Under Trump, US-Russia Relations Hit New Low. Foreign Policy.

Nougayrede, N. (2017). France's Gamble: As America Retreats, Macron Steps up. Foreign Affairs. 96, 5

NSS Book Layout FIN 121917. (2017). Retrieved from https://www.whitehouse.gov/wpcontent/uploads/2017/12/NSS-Final-12-18-2017-0905.pdf

Our Dishonest President (2017, April 2), Los Angeles Times. Retrieved from http://www.latimes.com/

Perper, R. (2018, October 14). Saudi Arabia Vows Retaliation against the US Sanction 'Threats' Following Jamal Khashoggi’s Disappearance. Business Insider.

Plecher, H. (2019, November 26). United States - Share of global gross domestic product (GDP) 2024.

Retrieved from https://www.statista.com/statistics/270267/unitedstates-share-of-globalgrossdomestic-product-gdp/

Price, N. (2017). Trump's Nuclear Crisis Was of His Own Making'. Foreign Policy, 23.

Remarks: Secretary Pompeo - United States Department of State. (2018). Retrieved from https://www.state.gov/secretary/remarks/2018/06/283305.htm

Remarks: Secretary Pompeo - United States Department of State. (2018). Retrieved from https://www.state.gov/secretary/remarks/2018/06/283305.htm

Sanger, D. E., \& Broad, W. J. (2017). A 'Cuban Missile Crisis in Slow Motion' in North Korea. New York Times, 16.

The complete list till March 2018 can be accessed at CNBC website, https://www.cnbc.com/2018/03/14/timeline-of-north-korea-missile-launches-intrumpfirst-year.html 
The Guardian View on Donald Trump in Britain: This was the Visit from the Hell. (2018). Guardian.

The Observer's view on Donald Trump's Foreign Policy. (2017, April 16). The Guardian. Retrieved from https://www.theguardian.com/commentisfree/2017/apr/15/observer-view-ondonald-trump-and-american-foreign-policy

Theil, S. (2017). Berlin's Balancing Act: Merkel Needs Trump-But Also Needs to Keep Her Distance. Foreign Affairs. 96, 9

Trump, D. (2018). Joint Statement of President Donald J. Trump of the United States of America and Chairman Kim Jong-un of the Democratic People Republic of Korea at the Singapore Summit. White House, 12.

UK Joins UN Nations Rejecting the US Recognition of Jerusalem as Israeli Capital. (2017, December 18). AOL.

Warrick, J., Nakashima, E., \& Fifield, A. (2017). North Korea now making missile-ready nuclear weapons, US analysts say. The Washington Post, 8. 